\title{
PENGUATAN PANWAS KABUPATEN MAMUJU DALAM MENGHADAPI PEMILIHAN GUBERNUR DAN WAKIL GUBERNUR PROVINSI SULAWESI BARAT TAHUN $2017^{1}$
}

\author{
Muhammad Yusri AR.2 \\ Universitas Sulawesi Barat \\ Email: muhammad.yisri@gmail.com
}

\begin{abstract}
Demokrasi ditingkat lokal tidak akan berjalan dengan baik kalau aspek-aspek fundamental dari penyelenggaraan Pilkada tidak diperhatikan. Sebagai lembaga pengawas Pilkada ditingkat kabupaten/kota, Panwaslih seharusnya tidak menjadi mesin teknokratis semata-mata, melainkan bertindak sebagai instrumen demokrasi. Dengan begitu, Pilkada akan terhindar dari problem-problem elektoral"
\end{abstract}

\section{A. Pendahuluan}

Demokrasi memang bukan satu tatanan yang sempurna untuk mengatur peri kehidupun manusia. Namun sejarah di manapun telah membuktikan, bahwa demokrasi sebagai model kehidupan bernegara memiliki peluang paling kecil dalam menistakan kemanusiaan. Oleh karena itu, meskipun dalam berbagai dokumentasi negara ini tidak banyak ditemukan kata demokrasi, para pendiri negara sejak zaman pergerakan berusaha keras menerapkan prinsip-prinsip negara demokrasi bagi Indonesia.

Tiada negara demokrasi tanpa pemilihan umum (pemilu), sebab pemilu merupakan instrumen pokok dalam menerapkan prinsip-prinsip demokrasi. Sesungguhnya, pemilu tidak saja sebagai arena untuk mengekspresikan kebebasan rakyat dalam memilih pemimpinnya, tetapi juga arena untuk menilai dan menghukum para pemimpin yang tampil di hadapan rakyat. Namun, pengalaman di berbagai tempat dan Negara menunjukkan bahwa pelaksanaan pemilu seringkali hanya berupa kegiatan prosedural politik belaka, sehingga proses dan hasilnya menyimpang dari tujuan pemilu sekaligus mencederai nilainilai demokrasi.

Kenyataan tersebut mengharuskan dilakukannya usaha yang tak henti untuk membangun dan memperbaiki sistem pemilu yang fair, yakni pemilu yang mampu menampung kebebasan rakyat dan menjaga kedaulatan rakyat. Para penyelenggara pemilu dituntut memahami filosofi pemilu, memiliki pengetahuan dan keterampilan teknis penyelenggaraan pemilu, serta kekonsistenan menjalankan peraturan pemilu, agar proses pemilu berjalan sesuai dengan tujuannya. Selanjutnya, hasil pemilu, yakni para pemimpin yang terpilih, perlu didorong dan diberdayakan terus menerus agar dapat menjalankan fungsinya secara maksimal; mereka juga perlu dikontrol agar tidak meyalahgunakan kedaulatan rakyat yang diberikan kepadanya.

\footnotetext{
${ }^{1}$ Tulisan ini pernah dipresentasikan dalam Tes Uji Kelayakan dan Kepatutan Seleksi Calon Anggota Panwaslih Kabupaten Mamuju untuk Pilkada Gubernur dan Wakil Gubernur Provinsi Sulawesi Barat Tahun 2017 yang diselenggarakan oleh Bawaslu Provinsi Sulawesi Barat pada tanggal 31 Mei 2016 bertempat di Hotel Pantai Indah Mamuju.

${ }^{2}$ Staf Pengajar di Jurusan Ilmu Politik Universitas Sulawesi Barat
} 
Dari aspek pengawasan pemilu, lembaga pengawas pemilu sering dianggap kurang menjalankan fungsi secara maksimal dalam mengelola kasuskasus pelanggaran dan penyelesaian sengketa pemilu. Hal tersebut sangatlah wajar mengingat amanat undang-undang meletakkan posisi lembaga pengawas pemilu berada pada kedudukan yang hanya sebatas mengkaji dan merekomendasikan temuan. Keterbatasan kewenangan yang dimiliki oleh Bawaslu dan jajarannya tersebut, sering menimbulkan kontroversi tentang penyelesaian sengketa pemilu dan acap kali mencederai demokrasi.

Oleh karena itu, dalam tulisan ini, penulis bermaksud untuk melihat problem-problem terkait kepemiluan, kedudukan lembaga pengawas pemilu dari masa ke masa, melihat demografi pemilu di kabupaten mamuju, peran lembaga pengawas pemilu (Bawaslu dan jajarannya), mulai dari pola pencegahan, penindakan, penyelesaian sengketa, sistem pengawasan pemilu yang diterapkan selama ini serta rekomendasi yang ditawarkan dalam sistem pengawasan pemilu.

\section{B. Problem Kepemiluan, Lembaga Pengawas dan Sistem Pengawasan Pemilu}

\section{Problem Kepemiluan}

Dalam sejarah pilkada di Indonesia, tak sedikit kepala daerah yang terjerat korupsi pada periode kepemimpinannya. Semenjak desentralisasi 2001 lalu hingga 2014, setidaknya ada 17 Gubernur yang pernah/ sedang menjabat berstatus tersangka. Di level kabupaten/ kota, ada 331 kepala/wakil kepala daerah berurusan dengan aparat hukum sebagai saksi, tersangka atau terpidana.

Dari segi proses pemilu, penyelenggaraan pilkada serentak untuk pertama kalinya di 264 daerah Indonesia terbilang sukses tanpa adanya persoalan yang cukup berarti. Namun, pemilu tidak bisa hanya ditinjau dari sudut pandang proses penyelenggaraan yang terdiri dari berbagai tahapan pelaksanaan semata. Hasil pemilu juga mesti menjadi perhatian.

Hasil pemilu yang dimaksud terdiri dari tiga hal. Pertama, bagaimana hasil pemilu mampu mendorong terciptanya pemerintahan daerah yang efektif untuk menghasilkan berbagai kebijakan publik dalam rangka merealisasikan visi-misi sampai dengan program yang diusung oleh kepala daerah terkait. Kedua, bagaimana kepala daerah terpilih memperoleh dukungan mayoritas di parlemen. Ketiga, bagaimana pemilu mampu menyederhanakan sistem kepartaian dari multipartai ekstrem menuju multipartai moderat.

\section{Problem Lembaga Pengawas Pemilu}

Sejauh pengertian penindakan adalah upaya nyata terhadap pelaku pelanggar hukum, maka Bawaslu dan jajarannya sesungguhnya tidak memiliki tugas dan wewenang untuk melakukan penindakan terhadap pelaku pelanggaran. Tugas dan wewenang mereka sebatas melakukan pengkajian dan 
merekomendasikan kepada institusi lain, bahwa telah terjadi pelanggaran. Institusi lain itulah yang melakukan penindakan hukum. Kecuali jika pengkajian dan rekomendasi dianggap sebagai bagian dari penindakan, maka hal itu harus diterima sebatas pengertian bahwa pengkajian dan rekomendasi merupakan rangkaian dari penindakan.

\section{Problem Pengawasan Pemilu}

Berdasarkan pantauan yang dilakukan oleh Tim Bawaslu RI tentang pelaksanaan pilkada serentak pada tahun 2015, mereka sempat memotret beberapa aspek yang dianggap paling rawan dan potensial memunculkan pelanggaran dalam pilkada tahun 2015. Adapun variabel, indikator dan pembobotan yang dinilai dalam indeks kerawanan pilkada oleh Bawaslu RI ada 5 hal, seperti : Pertama, menyangkut profesionalisme penyelenggara pemilu, yaitu sejauhmana independensi dan netralitas penyelenggara pemilu selama pilkada berlangsung? Kedua, persoalan politik uang, yaitu dengan mengukur kemiskinan suatu daerah, anggaran bansos dalam APBD, dan juga anggaran iklan pencitraan. Ketiga, akses pengawasan, yaitu, dengan melihat kondisi geografis suatu daerah, fasilitas listrik, fasilitas alat komunikasi, dan akses jalan. Keempat, tingkat partisipasi masyarakat, yaitu, dengan melihat tingkat partisipasi masyarakat dalam pileg maupun pilpres, jumlah relawan demokrasi atau Gerakan Sejuta Relawan Pengawas Pemilu (GSRPP), dan keberadaan pemantau di daerah. Kelima, keamanan daerah, yaitu dengan melihat ada tidaknya intimidasi ke penyelenggara pemilu, dan pengamatan terhadap sejarah kekerasan pemilu di suatu daerah. Selain kelima indikator tersebut, ada beberapa isu lain juga diamati, seperti : minimnya partisipasi perempuan dalam pilkada, efektifitas pemerintahan pasca pilkada yang dapat menimbulkan pemerintahan yang terbelah (divided government), fragmentasi partai politik pasca pilkada, dan munculnya politik kartel pasca pilkada.

Indikator-indikator tersebut diatas merupakan problem-problem pengawasan pemilu yang selama ini berlangsung di Indonesia.

\section{Kedudukan Bawaslu dan Jajarannya dalam Pemilu ke Pemilu}

Lembaga pengawas pemilu adalah khas Indonesia. Di Negara-negara yang berpengalaman menyelenggarakan pemilu demokratis, tidak memiliki lembaga pengawas. Standar internasional pemilu demokratis pun tidak mengharuskan pembentukan lembaga pengawas untuk menjamin ditaatinya semua peraturan pemilu. Penyelenggaraan pemilu 1955, yang merupakan pemilu pertama di Indonesia yang benar-benar berlangsung secara jujur, adil, tertib dan damai, juga tidak membentuk lembaga pengawas pemilu.

Undang-Undang No. 2 Tahun 1980 tentang Pemilihan Umum AnggotaAnggota Badan Permusyawaratan/Perwakilan Rakyat yang mengatur adanya badan baru yang bernama PANWASLAK PEMILU (Panitia Pengawas pelaksanaan Pemilihan Umum). Pengawas pemilu pada undang-undang ini dipimpin oleh 
pejabat kejaksaan dengan anggota muspika dan wakil partai peserta pemilu pada masing-masing tingkatan.

Undang-Undang No. 3 Tahun 1999 tentang Pemilihan Umum yang mengatur bahwa Panwaslu dibentuk ditingkat pusat, provinsi, kabupaten/kota, dan kecamatan. Pengawas pemilu pada undang-undang ini dipimpin oleh hakim dilingkungan peradilan dengan anggota dari unsur nonpartisan, seperti akademisi, tokoh LSM dan tokoh organisasi masyarakat.

Undang-Undang No. 12 Tahun 2003 tentang Pemilihan Umum Anggota DPR, DPD, dan DPRD dan Undang-Undang No. 23 Tahun 2003 tentang Pemilihan Umum Presiden dan Wakil Presiden, menegaskan untuk melakukan pengawasan pemilu, sehingga dibentuklah Panitia Pengawas Pemilu, Panitia Pengawas Pemilu Provinsi, Panitia Pengawas Pemilu Kabupaten/Kota, Panitia Pengawas Pemilu Kecamatan. Pengawas pemilu pada undang-undang ini dipimpin oleh seorang ketua yang ditunjuk dari anggota; sedang anggota panwas pemilu terdiri dari unsur tokoh masyarakat, perguruan tinggi, pers, kepolisian dan kejaksaan.

Pengaturan pengawas pemilu pilkada tahun 2005 diatur dalam UndangUndang-Undang No. 32 Tahun 2004 tentang Pemerintahan Daerah. Pengawas pemilu pada undang-undang ini dipimpin oleh seorang ketua yang ditunjuk dari anggota; sedang anggota panwas pemilu terdiri dari unsur tokoh masyarakat, perguruan tinggi, pers, kepolisian dan kejaksaan.

Undang-Undang No. 22 Tahun 2007 tentang Penyelenggara Pemilu. Pengawas pemilu pada undang-undang ini dipimpin oleh seorang ketua yang dipilih oleh anggota; sedangkan anggota terdiri dari unsur-unsur nonpartisan yang memiliki pengetahuan dan keterampilan tentang pengawasan pemilu.

Undang-Undang No. 15 Tahun 2011 tentang Penyelenggara Pemilu. Pengawas pemilu pada undang-undang ini dipimpin oleh seorang ketua yang dipilih oleh anggota; sedangkan anggota terdiri dari unsur-unsur nonpartisan yang memiliki pengetahuan dan keterampilan tentang pengawasan pemilu.

Undang-Undang No. 8 Tahun 2012 tentang Pemilu Legislatif Pengawas pemilu pada undang-undang ini dipimpin oleh seorang ketua yang dipilih oleh anggota; sedangkan anggota terdiri dari unsur-unsur nonpartisan yang memiliki pengetahuan dan keterampilan tentang pengawasan pemilu.

Undang-Undang No. 8 Tahun 2015 tentang Pemilihan Gubernur, Bupati dan Walikota. Pengawas pemilu pada undang-undang ini dipimpin oleh seorang ketua yang dipilih oleh anggota; sedangkan anggota terdiri dari unsur-unsur nonpartisan yang memiliki pengetahuan dan keterampilan tentang pengawasan pemilu.

Nomenklatur penindakan menimbulkan masalah tersendiri didalam sistem perundang-undangan dan sistem pengawasan pemilu di Indonesia, sebab dalam konsep penegakan hukum pemilu, lembaga pengawas pemilu sesungguhnya tidak melakukan langkah nyata terhadap pelaku pelanggaran hukum. Tugas dan wewenang lembaga pengawas pemilu disini hanya sebatas memberi rekomendasi kepada institusi lain yang berwenang (kepolisian, 
kejaksaan, KPUD dan DKPP). Apabila lembaga pengawas pemilu menemukan pelanggaran pidana, maka kasusnya diserahkan ke kepolisian, dan kepolisianlah yang menetapkan tersangka pelaku pelanggarannya. Dari kepolisian, kejaksaan mendudukkan pelaku di kursi terdakwa di pengadilan, dan kemudian hakim menjatuhkan vonis. Jadi, sesungguhnya lembaga pengawas pemilu tidak melakukan penindakan apapun.

Demikian juga dalam kasus pelanggaran administrasi. Disini lembaga pengawas pemilu hanya bertugas merekomendasikan kepada penyelenggara pemilu (KPU, KPU provinsi dan KPU kabupaten/kota), bahwa telah terjadi pelanggaran administrasi. Selanjutnya penyelenggara pemilu memastikan benartidaknya pelanggaran administrasi tersebut melalui pemeriksaan bukti dan saksi. Jika memang benar terjadi pelanggaran, maka penyelenggara baru menjatuhkan sanksi. Sedangkan jika pengawas pemilu menemukan kasus pelanggaran kode etik penyelenggara pemilu, pengawas cukup melaporkannya ke Dewan Kehormatan Penyelenggara Pemilu (DKPP). Selanjutnya DKPP yang akan menggelar persidangan untuk memastikan benar-tidaknya ada pelanggaran kode etik penyelenggara pemilu sebagaimana dilaporkan pengawas pemilu.

\section{Demografi Pemilu di Kabupaten Mamuju}

Rekapitulasi Data Pemilih Pilpres Tahun 2014 Provinsi Sulawesi Barat

\begin{tabular}{|c|c|c|c|c|c|}
\hline \multirow{2}{*}{ No. } & \multirow{2}{*}{ Provinsi } & \multicolumn{3}{|c|}{ Jumlah Pemilih } & Jumlah \\
\cline { 3 - 5 } & & Laki-Laki & Perempuan & JUMLAH & TPS \\
\hline 1. & Sulawesi Barat & 445.212 & 442.365 & $\mathbf{8 8 7 . 5 7 7}$ & 2.767 \\
\hline
\end{tabular}

Sumber : https://data.kpu.go.id

Rekapitulasi Daftar Pemilih Tetap Provinsi Sulawesi Barat Pada Pemilihan Legislatif 2014

\begin{tabular}{|c|l|c|c|c|c|c|c|}
\hline No. & \multirow{2}{*}{$\begin{array}{c}\text { Nama } \\
\end{array}$} & Kabupaten/Kota & Jumlah & Jumlah & Jumlah & \multicolumn{3}{|c|}{ Jumlah Pemilih } \\
\cline { 5 - 8 } & Kecamatan & Desa/Kel & TPS & L & P & L+P \\
\hline 1. & Mamasa & 17 & 178 & 488 & 59.783 & 57.869 & 117.652 \\
\hline 2. & Polewali Mandar & 16 & 167 & 827 & 149.996 & 158.762 & 308.758 \\
\hline 3. & Majene & 8 & 82 & 405 & 51.589 & 54.657 & 106.246 \\
\hline 4. & Mamuju & 16 & 153 & 800 & 127.162 & 120.263 & 247.425 \\
\hline 5. & Mamuju Utara & 12 & 63 & 300 & 54.416 & 48.778 & 103.194 \\
\hline \multicolumn{2}{|c|}{ TOTAL } & $\mathbf{6 9}$ & $\mathbf{6 4 3}$ & $\mathbf{2 . 8 2 0}$ & $\mathbf{4 4 2 . 9 4 6}$ & $\mathbf{4 4 0 . 3 2 9}$ & $\mathbf{8 8 3 . 2 7 5}$ \\
\hline
\end{tabular}

Sumber : https://www.scribd.com

Jumlah Pemilih Pada Pilkada Tahun 2015 di Kabupaten Mamuju

\begin{tabular}{|c|l|c|c|c|}
\hline No. & \multicolumn{1}{|c|}{ Kecamatan } & Jumlah Desa & Jumlah DPT & Jumlah TPS \\
\hline 1. & Mamuju & 8 & 36.378 & 104 \\
\hline 2. & Tapalang & 9 & 11.026 & 42 \\
\hline 3. & Tapalang Barat & 7 & 5.976 & 26 \\
\hline 4. & Simboro & 8 & 21.844 & 54 \\
\hline 5. & Bala-Balakang & 2 & 1.748 & 8 \\
\hline
\end{tabular}




\begin{tabular}{|c|l|c|c|c|}
\hline 6. & Kalukku & 13 & 34.297 & 107 \\
\hline 7. & Bonehau & 9 & 5.963 & 26 \\
\hline 8. & Kalumpang & 13 & 7.881 & 47 \\
\hline 9. & Papalang & 9 & 14.459 & 45 \\
\hline 10. & Sampaga & 7 & 9.898 & 37 \\
\hline 11. & Tommo & 14 & 15.006 & 55 \\
\hline JUMLAH TOTAL & $\mathbf{9 9}$ & $\mathbf{1 6 4 . 4 7 6}$ & $\mathbf{5 5 1}$ \\
\hline
\end{tabular}

Sumber : http://seputarsulbar.com (3 Oktober 2015)

\section{Daftar Dugaan Pelanggaran Pilkada Serentak 2015}

\begin{tabular}{|c|c|c|c|c|c|c|}
\hline \multirow[t]{2}{*}{ No. } & \multirow[t]{2}{*}{ Wilayah } & \multicolumn{2}{|c|}{ Dugaan Pelanggaran } & \multicolumn{2}{|c|}{ Tindak Lanjut Panwas } & \multirow[t]{2}{*}{ Jumlah } \\
\hline & & Laporan & Temuan & Dihentikan & Ditindaklanjuti & \\
\hline 1. & $\begin{array}{l}\text { Seluruh } \\
\text { Indonesia }\end{array}$ & $\begin{array}{c}2575 \\
(50.5 \%) \\
\end{array}$ & $\begin{array}{c}2524 \\
(49.5 \%) \\
\end{array}$ & $\begin{array}{c}2339 \\
(45.87 \%) \\
\end{array}$ & $\begin{array}{c}2760 \\
(54.13 \%) \\
\end{array}$ & 5099 \\
\hline 2. & $\begin{array}{l}\text { Prov. } \\
\text { Sulawesi } \\
\text { Barat } \\
\text { (Non } \\
\text { Pilgub) }\end{array}$ & $\begin{array}{c}37 \\
(46.84 \%)\end{array}$ & $\begin{array}{c}42 \\
(53.16 \%)\end{array}$ & $\begin{array}{c}57 \\
(72.15 \%)\end{array}$ & $\begin{array}{c}22 \\
(27.85 \%)\end{array}$ & 79 \\
\hline 3. & $\begin{array}{l}\text { Kab. } \\
\text { Mamuju } \\
\text { Utara }\end{array}$ & $\begin{array}{c}16 \\
(48.48 \%)\end{array}$ & $\begin{array}{c}17 \\
(51.52 \%)\end{array}$ & $\begin{array}{c}24 \\
(72.73 \%)\end{array}$ & $\begin{array}{c}9 \\
(27.27 \%)\end{array}$ & 33 \\
\hline 4. & $\begin{array}{l}\text { Kab. } \\
\text { Majene }\end{array}$ & $\begin{array}{c}2 \\
(13.33 \%)\end{array}$ & $\begin{array}{c}13 \\
(86.67 \%)\end{array}$ & $\begin{array}{c}11 \\
(73.33 \%)\end{array}$ & $\begin{array}{c}4 \\
(26.67 \%)\end{array}$ & 15 \\
\hline 5. & $\begin{array}{l}\text { Kab. } \\
\text { Mamuju } \\
\text { Tengah }\end{array}$ & $\begin{array}{c}3 \\
(30 \%)\end{array}$ & $\begin{array}{c}7 \\
(70 \%)\end{array}$ & $\begin{array}{c}9 \\
(90 \%)\end{array}$ & $\begin{array}{c}1 \\
(10 \%)\end{array}$ & 10 \\
\hline 6. & $\begin{array}{l}\text { Kab. } \\
\text { Mamuju }\end{array}$ & $\begin{array}{c}16 \\
(76.19 \%)\end{array}$ & $\begin{array}{c}15 \\
(71.43 \%)\end{array}$ & $\begin{array}{c}13 \\
(61.90 \%)\end{array}$ & $\begin{array}{c}18 \\
(85.71 \%)\end{array}$ & 21 \\
\hline
\end{tabular}

Sumber : Diolah dari Laporan Bawaslu RI dalam Pilkada Serentak 2015

\section{E. Penguatan Panwas Kabupaten : Optimalisasi Tugas dan Fungsi Menuju Pemilihan Gubernur Tahun 2017}

\section{Pemilu dalam Perspektif Pengawasan}

Undang-Undang Nomor 15 Tahun 2011 tentang Penyelenggara Pemilu menciptakan nomenklatur baru dalam bidang pengawasan pemilu atau penegakan hukum pemilu. Menurut undang-undang ini, Bawaslu dan jajajarnnya bertugas mengawasi penyelenggaraan pemilu dalam rangka pencegahan dan penindakan pelanggaran untuk terwujudnya pemilu yang demokratis. Dari obyek pengawasan itu, Bawaslu dan jajarannya diharapkan mengetahui apa yang harus dilakukan dalam rangka pencegahan dan penindakan, berdasarkan praktek pengawasan pemilu yang berlangsung selama ini. 


\section{Pencegahan Pelanggaran Pemilu}

Pengertian pencegahan mengandaikan adanya upaya yang harus dilakukan agar tidak terjadi hal-hal yang tidak diinginkan. Dalam konsep penegakan hukum, pencegahan berarti melakukan upaya-upaya agar tidak terjadi pelanggaran-pelanggaran hukum. Dengan demikian, dalam penegakan hukum pemilu atau pengawasan pemilu, pencegahan berarti melakukan upaya-upaya agar tidak terjadi pelanggaran hukum pemilu.

Dalam mendesain upaya-upaya pencegahan untuk meminimalisir pelanggaran dalam pemilu dapat dilihat pada beberapa hal, yaitu : Pertama, pemetaan potensi pelanggaran. Pemetaan potensi pelanggaran dapat dilihat pada tahapan pendaftaran peserta pilkada, pendaftaran pemilih, pencalonan, kampanye, pemungutan suara, penghitungan suara, penetapan hasil, penetapan calon terpilih, hingga pelantikan calon terpilih. Kedua, strategi pencegahan. Dalam mendesain strategi pencegahan, ada beberapa prinsip yang perlu diperhatikan, yaitu : (1). Strategi pencegahan harus mendorong terciptanya persaingan yang sehat dalam memperebutkan suara rakyat dikalangan peserta pemilu, sehingga siapapun peserta pemilu akan dihormati oleh rakyat. (2). Strategi pencegahan pelanggaran harus meningkatkan kontrol diantara para peserta pemilu dan diantara para calon, sehingga masing-masing berusaha menjaga diri agar tidak melakukan pelanggaran. (3). Strategi pencegahan harus melibatkan masyarakat agar mereka terhindar dari intimidasi dan jual beli suara, sehingga mereka bisa memberikan suaranya secara bebas, sekaligus menjaga sendiri keaslian suaranya dalam proses pemungutan dan penghitungan suara. (4). Penentuan bentuk dan jenis kegiatan pencegahan perlu di desain sedemikian rupa sehingga kampanye atau sosialisasi untuk mencegah pelanggaran pemilu mencerminkan karakter sosial masyarakat tersebut. dan Ketiga, Pernyataan melalui media massa. Salah satu bentuk kegiatan pencegahan pelanggaran yang paling sering dilakukan oleh lembaga pengawas pemilu adalah mengeluarkan pendapat melalui media massa. Hal ini memamng paling mudah dilakukan dan hasilnya bisa signifikan karena dapat diikuti oleh masyarakat luas. Bagaimanapun sebuah peristiwa harus dipahami secara utuh untuk mendapatkan penilaian yang tepat. Masalahnya bukan hanya sebatas pada siapa yang salah dan siapa yang benar, atau siapa yang harus bertanggungjawab dan siapa lepas tanggungjawab, tetapi juga terletak pada pemaknaan atas peristiwa. Disinilah media menjadi penting didalam menanamkan nilai-nilai demokrasi dan prinsip-prinsip pemilu demokratis dikalangan masyarakat luas.

\section{Penindakan Pelanggaran Pemilu}

Pengertian penindakan mengandaikan adanya langkah nyata terhadap pelaku pelanggaran hukum agar yang bersangkutan mendapat perlakuan yang setimpal atas pelanggaran yang dilakukannya. Dalam konsep penegakan 
hukum pidana, penindakan itu meliputi menetapkan seseorang sebagai tersangka untuk diproses hukum, mendudukkan sebagai terdakwa untuk disidang dipengadilan, dan menjatuhkan vonis terpidana untuk mendapatkan hukuman. Sementara dalam konsep penegakan hukum administrasi, penindakan itu meliputi menetapkan seseorang atau lembaga sebagai terlapor, mendudukkan seseorang atau lembaga sebagai tergugat, dan menyatakan seseorang atau lembaga sebagai pelanggar peraturan.

Dalam mendesain upaya-upaya penindakan dalam kerangka menindaklanjuti temuan-temuan pelanggaran didalam pemilu dapat dilihat pada beberapa hal, yaitu : Pertama, Pemetaan Jenis Pelanggaran. Dalam Undang-Undang No. 8 Tahun 2012, membedakan tiga jenis pelanggaran, yaitu : tindak pidana pemilu, pelanggaran administrasi pemilu, dan pelanggaran kode etik penyelenggara pemilu. (1). Tindak pidana pemilu dipahami sebagai tindak pidana pelanggaran dan atau kejahatan terhadap ketentuan tindak pidana pemilu. Seperti, memberi keterangan tidak benar dalam pengisian daftar pemilih, mengumumkan hasil survey pada masa tenang, menghilangkan hak pilih orang lain, dan petugas pemilu yang tidak menindaklanjuti temuan atau laporan pelanggaran. (2). Pelanggaran administrasi pemilu dipahami sebagai pelanggaran yang meliputi tata cara, prosedur dan mekanisme yang berkaitan dengan administrasi pelaksanaan pemilu dalam setiap tahapan pemilu diluar tindak pidana pemilu dan pelanggaran kode etik penyelenggara pemilu. (3). Pelanggaran kode etik penyelenggara pemilu dipahami sebagai pelanggaran terhadap etika penyelenggara pemilu yang berpedomankan sumpah dan janji sebelum menjalankan tugas sebagai penyelenggara pemilu. Kedua, Memahami Batas Waktu Penanganan Pelanggaran. Terbatasnya waktu yang diberikan untuk menangani pelanggaran membuat banyaknya laporan dan temuan pelanggaran pemilu tidak terselesaikan. Dalam catatan Bawaslu RI, terdapat 5099 kasus dugaan pelanggaran pilkada serentak yang diselenggarakan pada tahun 2015. Adapun kasus yang teridentifikasi dalam bentuk laporan sebanyak 2575 kasus dan temuan sebanyak 2524 kasus. Ketiga, Strategi Penindakan. Dalam usaha meningkatkan kinerja pengawasan dalam bidang penindakan, sekaligus untuk meningkatkan kredibilitas lembaga pengawas pemilu, maka Bawaslu dan jajarannya harus mengubah strategi penindakan. Bawaslu dan jajarannya tidak perlu menangani semua kasus pelanggaran yang ditemukan, Bawaslu dan jajarannya harus fokus pada kasus-kasus tertentu saja yang secara sosiologis berpengaruh terhadap proses penegakan hukum pemilu.

Kasus-kasus pelanggaran yang perlu ditangani oleh Bawaslu dan jajarannya harus memenuhi kriteria sebagai berikut : pertama, terkait langsung dengan hilang tidaknya hak pilih atau penggunaan hak pilih, seperti intimidasi pemilih dan penghapusan nama dalam DPT; kedua, mempengaruhi perilaku pemilih, seperti jual beli suara, penggunaan dana illegal dalam 
kampanye; ketiga, mengubah hasil pemilu, seperti pengubahan rekapitulasi penghitungan suara. Jika kasus tidak memenuhi kriteria tersebut, Bawaslu dan jajarannya tidak perlu memprosesnya, melainkan cukup digunakan sebagai bahan kampanye pencegahan pelanggaran pemilu. Dengan begitu, Bawaslu dan jajarannya bisa menghemat sumberdaya dan waktu.

\section{F. Penyelesaian Sengketa Pemilu}

Merujuk pada Undang-Undang Nomor 8 Tahun 2015 dan Peraturan Bawaslu Nomor 8 Tahun 2015 yang memberikan pengertian tentang sengketa pemilu sebagai sengketa yang terjadi antar peserta pemilu dan sengketa peserta pemilu dengan penyelenggara pemilu sebagai akibat dikeluarkannya keputusan KPU, KPU Provinsi, dan KPU Kabupaten/Kota. Berdasarkan pengertian itu, maka terdapat dua jenis sengketa, yakni : pertama, sengketa antar peserta pemilu, dan Kedua, sengketa antara peserta pemilu dan penyelenggara pemilu. Dalam penyelenggaraan pilkada gubernur dan wakil gubernur, jumlah keputusan KPU, KPU Provinsi, dan KPU Kabupaten/Kota sangat banyak, sesuai dengan proses pelaksanaan tahapan pemilu. Semuanya bisa menjadi penyebab terjadinya sengketa yang harus diselesaikan oleh Bawaslu dan Jajarannya.

Dalam pasal 157 Undang-Undang Nomor 8 Tahun 2015 menegaskan bahwa perkara perselisihan hasil pemilihan diperiksa dan diadili oleh badan peradilan khusus yang dibentuk sebelum pelaksanaan pilkada serentak. Sedangkan mahkamah konstitusi diberi waktu paling lama 45 (empat puluh lima) hari untuk memutuskan perkara perselisihan sengketa hasil pemilihan.

Beberapa hal yang perlu diperhatikan dalam proses penyelesaian sengketa pemilu, yaitu :Pertama, Potensi Sengketa. Berdasarkan pengalaman pilkada serentak tahun 2015 lalu, beberapa tahapan berpotensi untuk menjadi sengketa pemilu. Mulai dari pemutakhiran data pemilih, pencalonan, kampanye, masa tenang, logistik, pungut hitung sampai rekapitulasi suara. Salah satu tahapan yang berpotensi untuk menjadi sengketa pemilu adalah pemutakhiran data pemilih. keputusan KPU tentang penetapan daftar pemilih tetap (DPT) berpotensi besar menimbulkan masalah. Disatu sisi, pemilih yang namanya tidak terdapat dalam DPT, terbuka peluang untuk melaporkan petugas pemilu ke pengawas pemilu, karena mereka dianggap melanggar ketentuan tindak pidana pemilu. Disisi lain, calon kandidat kepala daerah bisa mengajukan gugatan sengketa pemilu ke lembaga pengawas pemilu apabila mereka merasa dirugikan oleh keputusan tersebut karena pemilih yang berpotensi memilih dirinya, namanya tidak masuk dalam DPT.

Kedua, Mekanisme Penyelesaian Sengketa. Proses sengketa pilkada diawali dari laporan oleh pasangan calon gubernur dan wakil gubernur. Pasangan calon yang berpotensi dirugikan atas penyelesaian sengketa Pemilihan dapat mengajukan diri sebagai pihak terkait dalam sengketa Pemilihan.

Untuk menjelaskan tentang mekanisme penyelesaian sengketa pemilu dapat dilihat pada table berikut : 


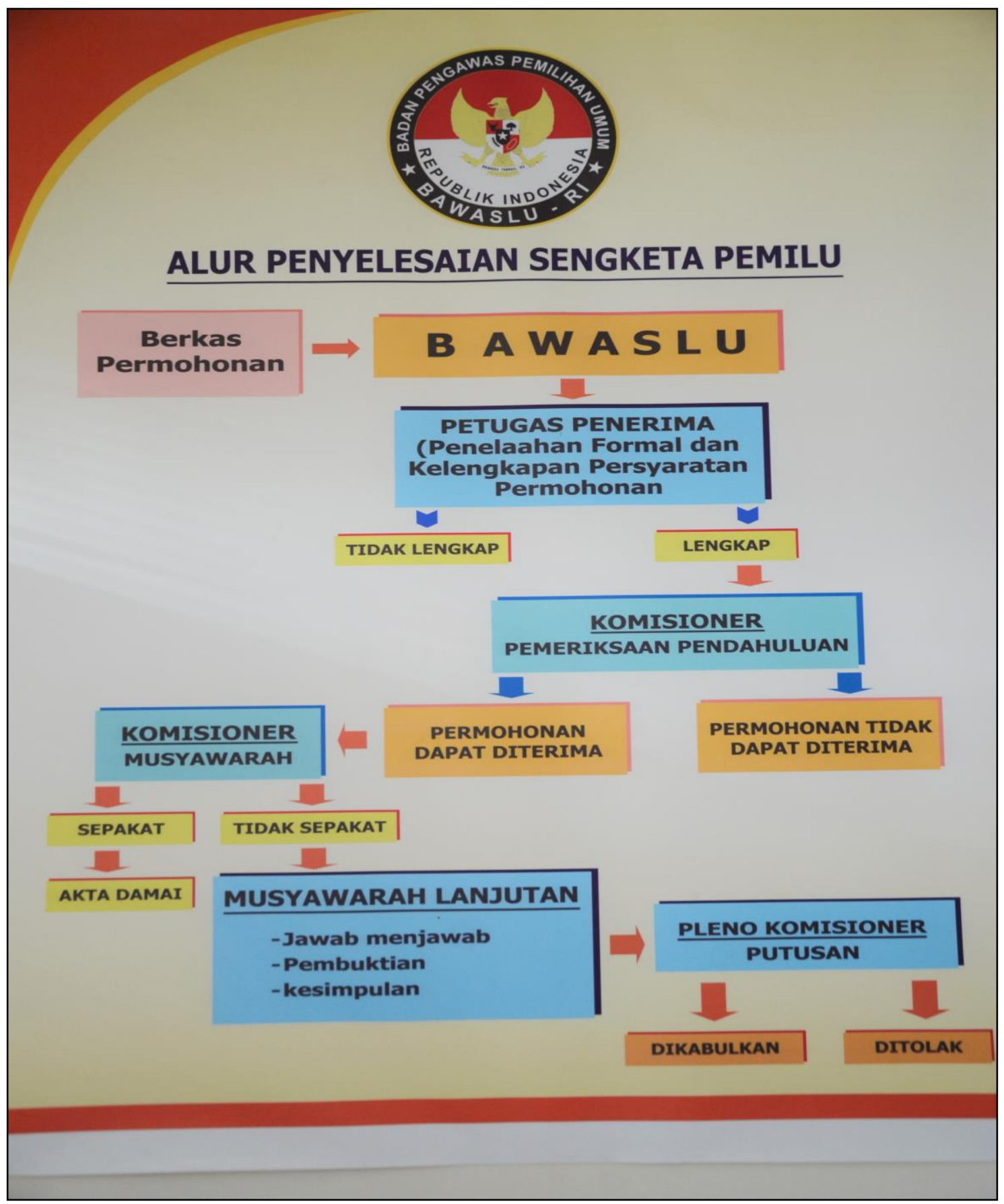

Sumber : www.bawaslu.go.id 


\section{G. Penutup dan Rekomendasi}

\section{Pencegahan}

Pertama, Pencegahan harus ditempatkan sebagai langkah strategis untuk memaksimalkan fungsi pengawasan. Kedua, Pencegahan harus mendorong terciptanya persaingan sehat dalam memperebutkan suara rakyat dikalangan peserta pemilu, sehingga siapapun pemenang pemilu akan dihormati oleh rakyat. Ketiga, Strategi pencegahan perlu meningkatkan kontrol diantara para peserta pemilu, sehingga masing-masing berusaha menjaga diri agar tidak melakukan pelanggaran. Keempat, Strategi pencegahan harus melibatkan masyarakat agar mereka terhindar dari intimidasi dan jual beli suara, sehingga mereka bisa memberikan suaranya secara bebas.

Strategi pencegahan perlu mempertimbangkan tiga hal, yaitu : Pertama, mengedepankan nilai-nilai demokrasi. Kedua, pelibatan masyarakat luas dalam pencegahan pelanggaran. Ketiga, penentuan bentuk dan jenis kegiatan pencegahan yang disesuaikan dengan kondisi budaya masyarakat.

\section{Penindakan}

Kasus-kasus pelanggaran yang ditangani oleh Bawaslu dan jajarannya perlu memenuhi Kriteria sebagai berikut : Pertama, terkait langsung dengan hilang tidaknya hak pilih atau penggunaan hak pilih, seperti intimidasi pemilih dan penghapusan nama dalam DPT. Kedua, mempengaruhi perilaku pemilih, seperti jual beli suara, penggunaan dana illegal dalam kampanye. Ketiga, mengubah hasil pemilu, seperti pengubahan rekapitulasi penghitungan suara.

Jika kasus tidak memenuhi criteria diatas, Bawaslu tidak harus memprosesnya, melainkan cukup digunakan sebagai bahan kampanye pencegahan pelanggaran pemilu.

\section{Penyelesaian Sengketa}

Sehubungan dengan fungsi penyelesaian sengketa, Bawaslu harus memperhatikan tiga hal berikut ini : Pertama, memastikan bahwa peraturan tentang penyelesaian sengketa sangat jelas dan pasti. Kedua, merekrut orang yang memiliki kemampuan untuk menyelesaikan sengketa, sehingga proses penyelesaian sengketa maupun hasilnya dihormati oleh semua pihak yang terlibat dalam penyelesaian. Ketiga, mengedepankan pertimbanganpertimbangan nilai-nilai demokrasi, prinsip-prinsip pemilu demokratis dan semangat konstitusional.

Melihat persoalan sistem pemilu dan sistem pengawasan pemilu mengantarkan kita pada kesimpulan bahwa tidaklah mudah mewujudkan pemilu yang demokratis. Pemilu tidak hanya sebatas orang (voters) datang kebilik suara dan memberikan suaranya, pemilu harus dimaknai sebagai bentuk pendidikan politik terhadap warga Negara melalui penyadaran-penyadaran yang dilakukan secara terus menerus tentang pentingnya suara mereka bagi keberlanjutan 
kehidupan dan dampak yang timbul setelah pemilu berlangsung. Lembaga pemilu semestinya memiliki peran yang sangat besar dalam menjamin keamanan suara pemilu, menjamin seiap proses tahapan tidak mencederai demokrasi. Untuk itu, lembaga pemilu memerlukan upaya secara kontinyu dalam mengevaluasi lembaganya, mendorong sistem yang lebih baik (memposisikan Bawaslu dan jajarannya menjadi lebih garang) sehingga kedepan perbaikan kualitas pemilu di Indonesia dapat tercapai. Inshaa Allah... 


\section{Daftar Referensi}

1. Didik Supriyanto Dkk, Penguatan Bawaslu ; Optimalisasi Posisi, Organisasi, dan Fungsi Dalam Pemilu 2014, Perludem, 2012.

2. Gregorius Sahdan \& Muhtar Haboddin, Evaluasi Kritis Penyelenggaraan Pilkada di Indonesia, IPD bekerjasama dengan Konrad Adenauer Stiftung, 2009.

3. Heroik M. Pratama \& Maharddhika, Prospek Pemerintahan Hasil Pilkada Serentak 2015, Perludem, 2016.

4. Laporan Bawaslu RI, Laporan Dugaan Pelanggaran Dalam Pemilihan Gubernur, Bupati Dan Walikota Serentak Tahun 2015, Bawaslu RI 2016.

5. Laporan Penelitian Bawaslu RI, Indeks Kerawanan Pilkada 2015, Bawaslu RI, 2015.

6. Sigit Pamungkas, Perihal Pemilu, Laboratorium Jurusan Ilmu Pemerintahan Fisipol UGM, 2009.

\section{Undang-Undang}

1. Undang-Undang Nomor 15 Tahun 2011 tentang Penyelenggara Pemilu

2. Undang-Undang Nomor 8 Tahun 2012 tentang Pemilu Legislatif

3. PERPU Nomor 1 Tahun 2014 tentang Pemilihan Gubernur, Bupati dan Walikota

4. Undang-Undang Nomor 1 Tahun 2014 tentang Penetapan Peraturan Pemerintah Pengganti Undang-Undang Nomor 1 Tahun 2014 Tentang Pemilihan Gubernur, Bupati, Dan Walikota Menjadi Undang-Undang

5. Undang-Undang Nomor 8 Tahun 2015 tentang Pemilihan Gubernur, Bupati dan Walikota

\section{Perbawaslu}

1. Perbawaslu No. 2 Tahun 2015 ttg Perubahan Perbawaslu No. 11 Tahun 2014 ttg Pengawasan Pemilu

2. Perbawaslu No. 3 Tahun 2015 ttg Perubahan Ketiga Perbawaslu No. 10 Tahun 2012 ttg Pembentukan, Pemberhentian, Dan Penggantian Antar Waktu Badan Pengawas Pemilihan Umum Provinsi, Panitia Pengawas Pemilihan Umum Kabupaten/Kota, Panitia Pengawas Pemilihan Umum Kecamatan, Pengawas Pemilihan Umum Lapangan, Dan Pengawas Pemilihan Umum Luar Negeri

3. Perbawaslu No. 4 Tahun 2015 ttg Pengawasan DPT Pemilihan

4. Perbawaslu No. 8 Tahun 2015 ttg Penyelesaian Sengketa Pemilihan

5. Perbawaslu No. 10 Tahun 2015 ttg Pengawasan Kampanye Pemilihan

6. Perbawaslu No. 11 Tahun 2015 ttg Pengawasan Dana Kampanye Pemilihan

7. Perbawaslu No. 12 Tahun 2015 ttg Pengawasan Logistik Pemilihan

8. Perbawaslu No. 13 Tahun 2015 ttg Pengawasan Pungut Hitung Pemilihan

9. Perbawaslu No. 14 Tahun 2015 ttg Pengawasan Rekapitulasi dan Penetapan Pemilihan 


\section{Sumber Internet}

1. http://www.bawaslu.go.id/id/profil/sejarah-pengawasan-pemilu

2. http://seputarsulbar.com

3. https://data.kpu.go.id

4. https://www.scribd.com 